\title{
Experimental model of acute osteomyelitis in rats
}

\section{Modelo experimental de osteomielite aguda em ratos}

Aldo Cunha Medeiros, Amália Cínthia Meneses Rêgo, Robson Macedo Filho, Irami AraújoFilho, Ítalo Medeiros Azevedo, Vítor Brasil Medeiros

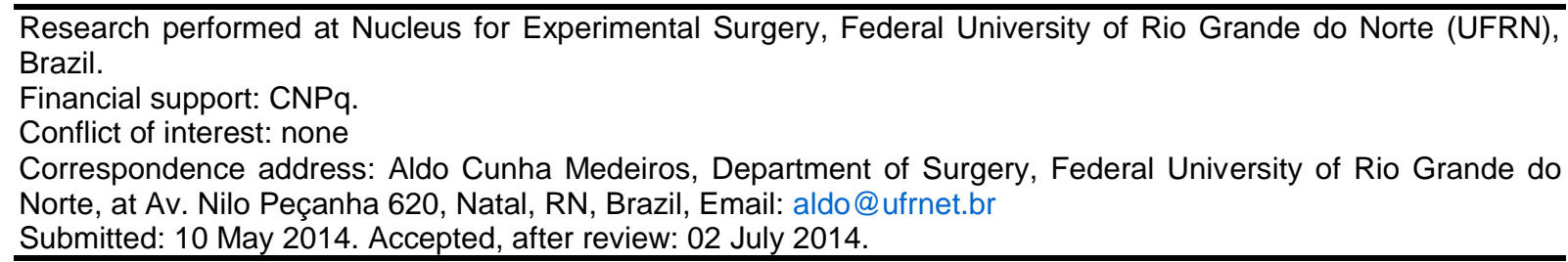

\section{ABSTRACT}

Purpose: The aim of this study was to characterize a model of acute osteomyelitis and the best time for bacterial recovery. Method: A segmental defect was surgically created in the rat femur, and contaminated with bacteria. The animals were allowed to recover in individual cages while the contamination progressed to an acute infection. At a later point in time, the defect was surgically debrided and washed with saline. To implement this model, the experiment was performed to determine the best time from contamination to the moment that would reliably result in acute infected osteomyelitis. The number of recovered bacteria was measured in 18 rats ( $n=6 /$ group) as a function of inoculum of Staphylococcus aureus (106 CFUs) and 3 times from contamination (3 days, 1week or 3 weeks). Results: Recovered bacteria occurred in all animals after 3 days, 1 week and 3 weeks. Bacterial inoculums time from each contaminated group had a significant effect on the mean of the number of recovered CFUs of bacteria. The mean log10 CFUs of recovered bacteria for each inoculum peaked at 1 week after contamination ( $7.84 \pm 0.22 \log 10 \mathrm{CFU})$. Consequently, the mean log10 CFUs of bacteria recovered at 1 week was significantly greater than the amount of bacteria recovered after 3 days $(4.63 \pm 0.10)$ and 3 weeks $(6.09 \pm 0.14)(p<0.001)$. Conclusion: This model of acute osteomyelitis was well characterized. Our data confirmed that 1 week after contamination was the optimal time to study bacterial recovery. We can infer that this model was viable and allows us to perform further studies on treatment of osteomyelitis with vetorized antimicrobials and other regimens of antibiotic therapy.

Keywords: Osteomyelitis. Staphylococcus aureus. Experimental model. Rats. 


\section{RESUMO}

Objetivo: O objetivo deste estudo foi caracterizar um modelo de osteomielite aguda e o melhor tempo para a recuperação bacteriana, a fim de utilização em futuros estudos. Métodos: Um defeito segmentar foi criado cirurgicamente em fêmur de ratos, e contaminado com bactérias. Os animais foram mantidos em gaiolas individuais, enquanto a contaminação progrediu para infecção aguda. Em um momento posterior, o defeito foi debridado cirurgicamente e lavado com solução salina. Este modelo experimental foi realizado para determinar o melhor momento da contaminação, que resultaria de forma confiável em osteomielite infectado aguda. O número de bactérias recuperadas foi medido em 18 ratos ( $n=6 /$ grupo), como uma função de inóculo de $S$. aureus (106 UFC) em três momentos a partir de contaminação (3 dias, 1 semana ou 3 semanas). Resultados: bactérias recuperadas ocorreram em todos os animais ao fim de 3 dias, 1 semana e 3 semanas. 0 tempo de inoculação bacteriana em cada grupo teve um efeito significativo sobre a média do número de UFCs de bactérias recuperadas. A média das UFC log10 de bactérias recuperadas para cada inóculo atingiu um pico de uma semana após a contaminação $(7,84$ $\pm 0,22 \log 10 \mathrm{CFU})$. Consequentemente, a média das UFCs log10 de bactérias recuperadas em 1 semana foi significativamente maior do que a quantidade de bactérias recuperadas ao fim de 3 dias $(4.63 \pm 0.10 \log 10 \mathrm{CFU})$ e 3 semanas $(6.09 \pm 0.14 \log 10 \mathrm{CFU}) \quad(p<0,001)$. Conclusão: Este modelo de osteomielite aguda foi bem caracterizado. Nossos dados confirmaram que uma semana após a contaminação pelo inóculo foi o tempo ideal para estudar a recuperação bacteriana. Podemos inferir que este modelo é viável e nos permite realizar mais estudos sobre o tratamento de osteomielite com antimicrobianos vetorizados e outros esquemas de antibioticoterapia.

Descritores: osteomielite. Staphylococcus aureus. Modelo experimental. Ratos.

\section{INTRODUCTION}

Osteomyelitis remains a frequent and severe disease ${ }^{1,2}$. The most important points for treatment are surgical debridement of the infected tissue, obliteration of dead space, adequate soft tissue coverage and a minimum 4-6 weeks of antimicrobial therapy ${ }^{3}$. However, there is a significant prevalence of failures and recurrences, even with vigorous treatment programs. Several types of treatment have been tested, and the prevalence of failures is not negligible.

The basic challenge for the administration of antimibrobials is the transfer of drugs to the right target at high doses, at the right time ${ }^{4}$. Drugs administered by oral or injectable ways suffer from the drawback of limited control release rate, unpredictable biodistribution to tissues and organs, in addition to harmful side effects and toxicity. The controlled release is appropriate to eliminate the above described drawbacks, enabling continuous release path. Drug delivery systems, vectorized by magnetic fields, have attracted significant interest from 
the last decade ${ }^{5-7}$. The use of polymeric nanoparticles in vivo are required to be hydrophilic with a physiological $\mathrm{pH}$. The conjugation of a drug to magnetic nanoparticles encapsulated in polymer has been shown to be a viable method for the controlled release of drugs to specific organs and tissues. An important advantage of magnetic nanoparticles is the use of an external magnetic field to attract them to the desired target, keeping them there in high concentrations until treatment is completed. This approach requires that the nanoparticles have sufficient magnetic power, biocompatibility and interactive functions at their surface ${ }^{8-10}$.

Concerning to the use of superparamagnetic nanoparticles as markers for antimicrobial treatment of infections, little is known specifically about osteomyelitis. This study aims to evaluate the feasibility of a model of experimental osteomyelitis in rats in our laboratory and the ideal time between contamination and bacterial recovery, for the purpose of using the model in our research line about magnetic vectoring of antimicrobials to treat the disease.

\section{METHODS}

The experiment was performed in adult male Wistar rats. The protocol and all experiments were conducted based on the guidelines of Law No. 11.794/2008, MCT, Brazil, which deals with the ethical use of animals in research. Pathogenic strains of Staphylococcus aureus resistant to oxacillin were obtained from an infected patient underwent surgical intervention.

\section{Experimental model of osteomyelitis}

A $10 \mathrm{~mm}$ segmental defect was created under aseptic conditions in the left femur in each of 18 Wistar rats. The animals were divided into 3 groups of 6 each, with the defects in all animals receiving inoculation of $S$. aureus. The groups were named according to the observation time after contamination: group1, 3 days; group 2, one week; group 3, three weeks.

\section{Bacterial strain}

The strain used for this study was a methicillin resistant $S$. aureus isolated from a patient with abdominal infection. An overnight culture was grown and washed in phosphatebuffered saline (PBS). Subsequently, aliquots were prepared. The numbers of viable colony forming units (CFU) were determined by serial dilution and plating on blood agar. At the day of surgery a fresh aliquot was defrosted, and a bacterial suspension of approximately $1 \times 10^{6}$ $\mathrm{CFU} / \mathrm{ml}$ was prepared in PBS.

\section{Surgical procedures}

Creation of femur defect: The rats were anesthetized with xilazine $(20 \mathrm{mg} / \mathrm{Kg})$ and ketamine $(50 \mathrm{mg} / \mathrm{Kg})$ i.p. Using aseptic technique, a longitudinal incision was made over the anterolateral femur. The entire length of the femoral shaft was exposed by carefully separating the vastus lateralis and biceps femoris muscles. All attached muscles and periosteum were stripped from the femoral shaft. The local bone marrow was removed by 
saline lavage, and the defect created in the medullary cavity was filled with a small block of polymerized bone cement (Jectos $\AA$ ), to act as foreign body for intramedullary infection.

\section{Contamination of femur defect}

The periosteal and fascial layers were closed over the cortical defect, and $0.1 \mathrm{ml}$ of $10^{6} \mathrm{CFU}$ of $S$. aureus per $\mathrm{ml}$ was injected into the medullary space surrounding the bone cement. The wound was sutured with mononylon 4-0 (Ethicon, São Paulo, Brazil). The animals received water and food ad libitum and were allowed full activity in their cages postoperatively, and were monitored daily for signs of systemic infection. Postoperative pain was controlled with meperidine $10 \mathrm{mg} / \mathrm{Kg}$ s.c. por 3 days.

\section{Bacteriologic analysis}

After 3 days, 1 week, and 3 weeks, by using the previous anesthesia and surgical approach, the defect area was exposed and swab specimens for culture were taken from the bone defect itself and from the surrounding area of soft tissues in order to confirm the success of the induction of staphylococcal bone infection. The swab specimens were cultured onto the surface of sheep blood agar, and incubated at $37^{\circ} \mathrm{C}$ for $48 \mathrm{~h}$. Results were expressed as the $\log _{10}$ number of recovered CFUs of $S$. aureus per gram of tissue.

\section{Statistical analysis}

The significance of differences between groups was calculated by one-way ANOVA, followed by method of multiple comparisons Tukey test. A $p<0.05$ was considered significant. All statistical analyzes were performed using BioEstat 5.0 software, Brazil.

\section{RESULTS}

Recovered bacteria occurred in all animals after 3 days, 1 week and 3 weeks. Bacterial inoculums time from each contaminated group had a significant effect on the mean of the number of recovered CFUs bacteria. The mean $\log _{10}$ CFUs of recovered bacteria for each inoculum peaked at 1 week after contamination (7.84 $\left.\pm 0.22 \log _{10} \mathrm{CFU}\right)$. Consequently, the mean $\log _{10}$ CFUs of bacteria recovered at 1 week was significantly greater than the amount of bacteria recovered after 3 days and 3 weeks $(p<0.001)$. These data are summarized in Table 1. 
Table 1 - Degree of bacterial colonization in infected bone defects in rat osteomyelitis model, 3 days, 1 week and 3 weeks after surgery.

\begin{tabular}{ccccc}
\hline $\begin{array}{c}\text { Baterial } \\
\text { inoculum }\end{array}$ & \multicolumn{3}{c}{ Time from contaminatio } & \multirow{2}{*}{ p-value } \\
\cline { 2 - 4 } & 3 days & 1 week & 3 weeks & \\
\hline $10^{6}$ CFU & $\begin{array}{c}4.63 \pm 0.10 \\
\left(\log _{10} \mathrm{CFU}\right)\end{array}$ & $\begin{array}{c}7.84 \pm 0.22 \\
\left(\log _{10} \mathrm{CFU}\right)\end{array}$ & $\begin{array}{c}6.09 \pm 0.14 \\
\left(\log _{10} \mathrm{CFU}\right)\end{array}$ & $<0.001$ \\
\hline
\end{tabular}

Data shown as mean \pm standard deviation. P-value analysis by ANOVA. Multiple comparisons for time inoculums after 3 days, 1 week and 3 weeks. (Tukey test)

\section{DISCUSSION}

Osteomyelitis is a frequent complication after trauma induced open fractures ${ }^{11}$. Nevertheless, infection following total joint replacement (clean surgery) remains a major problem $^{12}$. In many cases implant infections require removal of the implant, with the associated morbility and mortality and high economic costs. The most frequent pathogenic organism in arthroplasty infections is Staphylococcus. In staphylococcal implant infections, some complications, such as osteolysis, may be influenced by increased cytokine production ${ }^{13}$. Furthermore, an erroneous diagnosis of osteomyelitis may produce a chronic infection that is usually resistant to treatment ${ }^{14}$. Many factors are believed to contribute to the difficulty with treatment. The presence of fixation hardware is particularly troublesome. The fracture stability provided by the implant is essential for both bone healing and resolution of inflammation and infection ${ }^{15,16}$.

The rat was selected for our proposed model of osteomyelitis because infection can be established with great consistency in the rat, and the resulting infection is histopathologically similar to human post-traumatic osteomyelitis ${ }^{17,18}$. The segmental defect of critical size was included in the model because it has been successfully used in the rat by a number of investigators who study osteomyelitis ${ }^{10-21}$.

In order to fully implement this model, it was important to establish an appropriate contaminating bacterial inoculum and time from contamination that would reliably produce an infection, and not cause sufficient bony damage that would seriously compromise results. Chen et al (2005) ${ }^{22}$ studied bone contamination over de time (1-4 week) and showed that the number of recovered CFUs of bacteria for all contaminating inocula peaked at 1 week and then steadily declined over the next 3 weeks. Our results confirmed that 1 week is the best time for bacteria recovery after bone contamination. The occurrence of bony lysis progressively increased over the 4 weeks. Given this finding, and the fact that the bacterial census and bony lysis were greater, and the fixation stiffness lower, for the high bacterial inocula, a choice of 1 week would hypothetically represent an optimal contamination time ${ }^{22}$. Once again, in our study this optimal contamination time was confirmed. At this time point, the defect was found to still be in a period of acute infection as reflected by a large amount of local fluid infiltration and tissue swelling. This paper is part of a series works from our research line, infection in surgery ${ }^{23-27}$. 


\section{CONCLUSION}

This model of acute osteomyelitis with important features was characterized. Our data confirmed that the optimal time to study contamination and bacterial recovery was 1 week. We can infer that this model was viable and will be useful to continue the line of research about treatment of osteomyelitis with vetorized antimicrobials with superparamagnetic nanoparticles and other regimens of antibiotic therapy.

\section{REFERENCES}

1. Cierny G, Mader J T, Penninck J J. A clinical staging system for adult osteomyelitis. Clin Orthop. 2003;414:7-24.

2. Ziran B H, Rao N, Hall R A. A dedicated team approach enhances outcomes of osteomyelitis treatment. Clin Orthop. 2003;414:31-6.

3. Shuford J A, Steckelberg J M. Role of oral antimicrobial therapy in the management of osteomyelitis. Curr Opin Infect Dis. 2003;16:515-9.

4. McKee $M D$, Wild $L M$, Schemitsch $E H$, Waddell $J P$. The use of an antibioticimpregnated, osteoconductive, bioabsorbable bone substitute in the treatment of infected long bone defects: early results of a prospective trial. J Orthop Trauma. 2002;16:622-7.

5. Kanellakopoulou K, Giamarellos-Bourboulis E J. Carrier systems for the local delivery of antibiotics in bone infections. Drugs 2000;59:1223-32.

6. Kanellakopoulou K, Kolia M, Anastassiadis A, Korakis T, Giamarellos- Bourboulis E J, Andreopoulos A, Dounis E, Giamerellou H. Lactic acid polymers as biodegradable carriers of fluoroquinolones: an in vitro study. Antimicrob Agents Chemother. 1999; 43:714-6.

7. Orive G, Hernandez RM, Gascon AR, Domınguez-Gil A, Pedraz JL. Drug delivery in biotechnology: present and future. Curr Opin Biotechnol. 2003;14:659-64.

8. Neuberger TS, Bernhard $H$, Heinrich $H$, Margarete VRB. Superparamagnetic nanoparticles for biomedical applications: Possibilities and limitations of a new drug delivery system. J Magn Magn Mater. 2005;293:483-7.

9. Pankhurst QA, Connolly J, Jones SK, Dobson J. Application of magnetic nanoparticles in biomedicine. J Phys D: Appl Phys. 2003;36:167-9.

10. Shinkai M. Functional magnetic particles for medical application. J Biosci Bioeng. 2002;94:606-13.

11. Tsukayama DT. Pathophysiology of posttraumatic osteomyelitis. Clin Orthop. 1999;360:22-9.

12. Hanssen $A D$, Rand JA. Evaluation and treatment of infection at the site of a total hip or knee arthroplasty. J Bone Joint Surg Am. 1998;80:910-22.

13. Lassus J, Salo J, Jiranek WA, Santavirta S, Nevalainen J, Matucci-Cerinic M, et al. Macrophage activation results in bone resorption. Clin Orthop. 1998;352:7-15.

14. Klosterhalfen B, Peters KM, Töns C, Hauptmann S, Klein CL, Kirkpatrick CJ. Local and systemic inflammatory mediator release in patients with acute and chronic posttraumatic osteomyelitis. J Trauma. 1996;40:372-8.

15. Klein $P$, Schell $H$, Streitparth $F$, et al. The initial phase of fracture healing is specifically sensitive to mechanical conditions. J Orthop Res. 2003;21:662-9.

16. Worlock $P$, Slack R, Harvey L, Mawhinney $R$. The prevention of infection in open fractures: an experimental study of the effect of fracture stability. Injury. 1994;25:31-8. 
17. Cremieux A-C, Carbon C. Experimental models of bone and prosthetic joint infections. Clin Infect Dis. 1997;25:1295-302.

18. Rissing JP. Animal models of osteomyelitis: knowledge, hypothesis, and speculation. Infect Dis Clin N Am. 1990;4:377-90.

19. Lieberman JR, Daluiski A, Stevenson S, et al. The effect of regional gene therapy with bone morphogenetic protein-2-producing bone-marrow cells on the repair of segmental femoral defects in rats. J Bone Joint Surg. 1999;81A:905-17.

20. Stevenson S, Li XQ, Davy DT, et al. Critical biological determinants of incorporation of non-vascularized cortical bone grafts: quantification of a complex process and structure. J Bone Joint Surg. 1997;79A:1-16.

21. Wolff D, Goldberg VM, Stevenson S. Histomorphometric analysis of the repair of a segmental diaphyseal defect with ceramic and titanium fibermetal implants: effects of bone marrow. J Orthop Res. 1994;12:439-46.

22. Chen X, Tsukayama DT, Kidder LS, Bourgeault CA, Schmidt AH, Lew WD. Characterization of a chronic infection in an internally-stabilized segmental defect in the rat femur. J Orthop Res. 2005 Jul;23(4):816-23.

23. Medeiros V B, Azevedo IM, Rego, ACM, Araujo-Filho I, Carvalho MDF, Medeiros A C. . Attenuation of lung injury using simvastatin in a rat sepsis model. $\mathrm{J}$ Surg $\mathrm{Cl}$ Res. 2012;3:1-8.

24. Torres J L, Araujo-Filho I, Araujo MLM, Rego ACM, Sá MV, Medeiros VB, Tôrres SL, Azevedo IM, Medeiros AC. Triclosan-coated polyglactin-910 for closure of infected abdominal wall of rats with peritonitis. J Surg Cl Res. 2012;3:9-16.

25. Carvalho MDF, Azevedo IM, Medeiros AC. Duration of major surgery and its influence in surgical infection. J Surg CI Res. 2011; 2: 59-68.

26. Carvalho MDF, Silvestre IT, Risuenho AJG, Rego ACM, Araujo-Filho I, Azevedo IM, Medeiros A C. Sildenafil as a vasodilatatory madiator in the treatment of abdominal sepsis. J Surg CI Res. 2011;2:78-86.

27. Jacome DT, Rego ACM, Azevedo IM, Egito EST, Medeiros AC. Effect of simvastatin in abdominal sepsis of diabetic rats. Rev Col Bras Cir. 2010; 37:39-44. 